5 Hubert R, Weber JL, Schmitt K, Zhang L, Arnheim N. A new source of polymorphic DNA markers for sperm typing: analysis of microsatellite repeats in single cells. $\mathrm{Am}$ typing: analysis of microsatellite

6 Kristjansson K, Chong SS, Van den Veyver IB, Subramanian S, Snabes MC, Hughes MR. Preimplantation single cell analyses of dystrophin gene deletions using whole genome amplification. Nat Genet 1994;6:19-23.

7 Snabes MC, Chong SS, Subramanian SB, Kristjansson K, DiSepio D, Hughes MR. Preimplantation single-cell analysis of multiple genetic loci by whole-genome amplification Proc Natl Acad Sci USA 1994;91:6181-5.
8 Barrett MT, Reid BJ, Joslyn G. Genotypic analysis of multiple loci in somatic cells by whole genome amplification. Nucleic Acids Res 1995;23:3488-92.

9 Zhuang Z, Roth MJ, Emmert-Buck MR, Lubensky IA, Liotta LA, Solomon D. Detection of the von HippelLindau gene deletion in cytologic specimens using microdissection and the polymerase chain reaction. Acta Cytol 1994;38:671-5.

10 Emmert-Buck MR, Bonner RF, Smith PD, Chuaqui RF, Zhuang Z, Goldstein SR, et al. Laser capture microdissection. Science 1996;274:998-1000.

\title{
A PCR-SSP method for detecting the Cys282Tyr mutation in the HFE gene associated with hereditary haemochromatosis
}

\author{
David Smillie
}

\begin{abstract}
Hereditary haemochromatosis is a common genetic disorder that causes hyperabsorption of dietary iron, leading to increased deposition and various organic diseases. Early diagnosis is important if effective treatment is to be applied and the iron overload corrected before the onset of clinical symptoms. Recently, a candidate gene has been identified in which a single point mutation shows a very close association with hereditary haemochromatosis. A polymerase chain reaction method using sequence specific primers (PCRSSP) is described that, in conjunction with a simple DNA extraction method, would provide a specific diagnostic test or rapid screening procedure for this putative haemochromatosis associated mutation.

( Clin Pathol: Mol Pathol 1997;50:275-276)
\end{abstract}

Keywords: haemochromatosis; PCR-SSP; HFE gene; rapid screen

Haemochromatosis is transmitted as an autosomal recessive trait with a homozygosity frequency of $0.005-0.008$ and an estimated carrier frequency of $10 \%$ among individuals of North European origin. Although a link between haemochromatosis and the human leucocyte antigen (HLA) allele, HLA-A3, was described over 20 years ago, ${ }^{1}$ a much closer association has now been found with a mutation in a newly recognised gene, assigned the name.HFE (the accepted representation for the haemochromatosis locus approved by the Genome Database Nomenclature Committee). ${ }^{2}$ This gene belongs to the major histocompatibility complex (MHC) class I related gene family and is situated $4.5 \mathrm{Mb}$ telomeric to HLA-A. The mutation, whereby
$\mathrm{G}$ is replaced by $\mathrm{A}$ at nucleotide position 845 in the cDNA sequence $(845 \mathrm{G} \rightarrow \mathrm{A})$, results in the substitution of tyrosine for cysteine at amino acid position 282 in the transcribed protein (Cys282Tyr); this critically affects an intramolecular disulphide bond. ${ }^{3}$ It is possible that the products of MHC class I related genes are involved in iron metabolism and that this function is compromised by a mutation that affects the structure of the gene product.

Over $83 \%$ of haemochromatosis patients are homozygous for the Cys282Tyr mutation in the HFE gene, ${ }^{3-6}$ compared with $\sim 0.2 \%$ in normal controls. The PCR-SSP method described here allows rapid and specific typing for this haemochromatosis associated mutation.

\section{Methods}

DNA was extracted from $2 \mathrm{ml}$ anticoagulated blood by a simple salting out method $^{7}$ and DNA concentration adjusted to $50 \mathrm{ng} / \mu \mathrm{l}$.

Polymerase chain reaction (PCR) amplification was carried out in a reaction volume of $10 \mu \mathrm{l}$, consisting of $20 \mathrm{mM}$ ammonium sulphate, $75 \mathrm{mM}$ Tris- $\mathrm{HCl} \quad(\mathrm{pH} \mathrm{9.0)}, 0.01 \%$ Tween, $1.5 \mathrm{mM} \mathrm{MgCl}_{2}, 200 \mu \mathrm{M}$ dNTPs, $1.0 \mu \mathrm{M}$ specific primers (Oswel, Southampton,

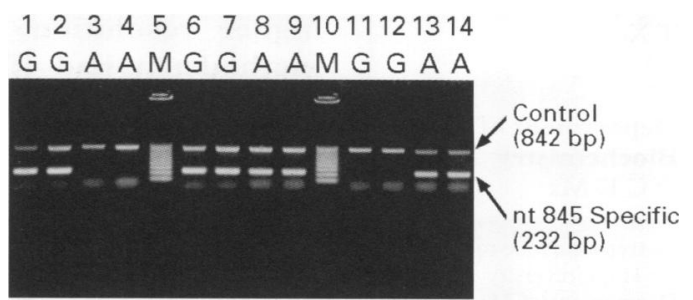

Figure 1 Gel electrophoresis of PCR products from three individuals (I-III). Lanes 1-4 (individual I), nucleotide 845G/G, Cys282Tyr-l-; Lanes 6-9 (individual II), nucleotide 845G/A, Cys282Tyr -1+; Lanes 11-14 (individual III), nucleotide 845A/A, Cys282Tyr +/+ Lanes 5 and 10, molecular markers (100 base pair ladder). 
UK), $0.25 \mu \mathrm{M}$ control primers, $0.5 \mathrm{U}$ DNA polymerase (Advanced Biotechnologies, Epsom, UK), and $50 \mathrm{ng}$ genomic DNA. One duplicate reaction set was specific for the normal sequence $(845 \mathrm{G})$ and a second reaction set was specific for the mutated sequence $(845 \mathrm{~A})$; both reaction sets used a common forward primer (5'-AAGGTGACACATCATGTGACC-3'), with a reverse primer specific for either 845G (5'-CTGGGTGCTCCACCTGGC-3'), or $845 \mathrm{~A}$ (5'-CTGGGTGCTCCACCTGGT-3'), resulting in a PCR product of 232 base pairs. Control primers, which amplified an 842 base pair fragment of the human growth hormone gene ${ }^{8}$ were included in all reactions. Amplification conditions involved an initial denaturation step for one minute at $96^{\circ} \mathrm{C}$, followed by five cycles consisting of denaturation for 25 seconds at $96^{\circ} \mathrm{C}$, annealing for 45 seconds at $70^{\circ} \mathrm{C}$, and extension for 30 seconds at $72^{\circ} \mathrm{C}$, then a further 21 cycles where the annealing temperature was lowered to $65^{\circ} \mathrm{C}$, plus four cycles where annealing was for one minute at $55^{\circ} \mathrm{C}$, and extension was for two minutes at $72^{\circ} \mathrm{C}$. A final extension step for five minutes at $72^{\circ} \mathrm{C}$ completed the amplification.

\section{Results and discussion}

The duplicate reaction sets typing for either $845 \mathrm{G}$ or $845 \mathrm{~A}$ were analysed by electrophoresis on a $1.5 \%$ agarose gel; PCR products were visualised by staining with ethidium bromide and photographed under ultraviolet illumination. Results from three representative individuals are shown in fig 1 . The results demonstrate that the PCR-SSP method is highly specific for the haemochromatosis associated mutation $845 \mathrm{G} \rightarrow \mathrm{A}$ in the HFE gene and that the method could be used as an aid to diagnosis, or for screening purposes.

I am very grateful to Dr Mark Worwood (Department of Haematology, University of Wales College of Medicine) for his kind gift of DNA for validation purposes. Primers were designed from sequence data for the haemochromatosis gene deposited in Genbank (Accession number U60319).

1 Simon M, Bourel M, Fauchet R, Genetet B. Association of $\vec{O}$ HLA-A 3 and HLA-B14 antigens with idiopathic haemoHLA-A3 and HLA-B14 antigens
chromatosis. Gut 1976;17:332-4.

2 Bodmer JG, Parham P, Albert ED, Marsh SGE. Putting a hold on 'HLA-H'. Nat Genet 1997;15:234-5.

3 Feder JN, Guirke A, Thomas W, Tsuchihashi Z, Ruddy DA, Basava A, et al. A novel MHC class I-like gene is mutated in patients with hereditary haemochromatosis. Nat Genet 1996;13:399-408.

4 Jazwinsa Powell LW, et al. Haemochromatosis and HLA-H. Nat G Powell LW, et al. Haemochromatosis and HLA-H. Nat $\mathrm{G}$
Genet 1996;14:249-51.

5 Jouanolle AM, Gandon G, Jézéquel P, Blayau M, Campion 윽 $\mathrm{ML}$, Yaouanq J, et al. Haemochromatosis and HLA-H. Nat Genet 1996;14:251-2.

6 Beutler E. Genetic irony beyond haemochromatosis: clinical effects of HLA-H mutations. Lancet 1997;349:296-7.

7 Miller SA, Dykes DD, Polesky HF. A simple salting out procedure for extracting DNA from human nucleated cells. cedure for extracting DNA from

8 Guttridge MG, Burr C, Klouda PT. Identification of HLA$\mathrm{B} 35, \mathrm{~B} 53, \mathrm{~B} 18, \mathrm{~B} 5, \mathrm{~B} 78$ and B17 alleles by the polymerase chain reaction using sequence-specific primers (PCRSSP). Tissue Antigens 1994;44:43-6.

\title{
High resolution single strand conformation polymorphism analysis using formamide and ethidium bromide staining
}

\author{
T Xie, S L Ho, O C K Ma
}

University

Department of

Medicine, University

of Hong Kong, Hong

Kong

T Xie

S L Ho

Department of Clinical Biochemistry

$\mathrm{O} \mathrm{C} \mathrm{K} \mathrm{Ma}$

Correspondence to:

Dr Ho, University

Department of Medicine,

University of Hong Kong

Queen Mary Hospital, Hong

Kong.

Accepted for publication 14 August 1997

\begin{abstract}
Single strand conformation polymorphism (SSCP) analysis using ethidium bromide can be improved by adding formamide as the denaturant. This gives higher resolution than previous SSCP methods; it had $100 \%$ sensitivity in the discrimination of 14 PCR samples from two different genes, even for a long fragment close to the upper limit of 250 base pairs. This modified procedure is a rapid, simple, safe, and yet highly sensitive method for detecting structural differences in DNA fragments.

(F Clin Pathol: Mol Pathol 1997;50:276-278)
\end{abstract}

Keywords: single strand conformation polymorphism; formamide; ethidium bromide
Polymerase chain reaction (PCR) amplifica tion of DNA fragments followed by single strand conformation polymorphism (SSCP) analysis is a sensitive method for detecting $\stackrel{?}{+}$ genetic polymorphisms or mutations. Detection by autoradiography ${ }^{1}$ or silver staining ${ }^{2}$ is time consuming, costly, and inconvenient. Non-isotopic SSCP (cold SSCP) using ethid- $\stackrel{\mathbb{2}}{2}$ ium bromide staining ${ }^{34}$ facilitates the rapid identification of structural changes in PCR 8 products. Currently, the denaturant used most frequently in cold SSCP is either sodium hydroxide $^{4}$ or methylmercury hydroxide. ${ }^{3}$ The $\stackrel{?}{?}$ former has been reported in some cases to yield inconsistent results ${ }^{3}$; the latter is an extremely toxic and volatile compound ${ }^{5}$ and great care has to be taken to avoid skin contact with methylmercury and inhalation of its aerosol. 